\title{
Germination AND EMERgence OF TRUMPet Flower (Tecoma stans) UNDER DIFFERENT ENVIRONMENTAL CONDITIONS ${ }^{1}$
}

\author{
Germinação e Emergência de Amarelinho (Tecoma stans) sob Efeito de Diferentes Condições \\ Ambientais
}
REIS, F.C. ${ }^{2}$, MEDINA SOTOMAYOR, J.F. ${ }^{3}$, GARCIA, D.B. ${ }^{4}$, BARROSO, A.A.M. ${ }^{2}$, ALBRECHT, A.J.P. ${ }^{2}$, and FILHO, R.V. ${ }^{2}$

\begin{abstract}
The aim of this work was to analyze the effect of temperature and light intensity on trumpet flower seed germination, as well as the effect of seeding depth on its emergence. To study the influence of temperature, nine temperature intervals were evaluated, ranging from 15.0 to $40.0^{\circ} \mathrm{C}$. A randomized block design experiment was used with five replications and 20 seeds per replication, and performed twice. To evaluate light intensity on seed germination, a randomized experimental design was used with eight replications and 25 seeds per replication. The treatments applied were: photoperiod with temperature alternation; photoperiod with constant temperature; darkness with temperature alternation; and darkness with constant temperature. The photoperiod consisted of 8 hours of light and 16 hours of darkness, and the constant temperature was $25^{\circ} \mathrm{C}$. The treatments with temperature alternations were established with 8 hours at $30^{\circ} \mathrm{C}$, and 16 hours at $20^{\circ} \mathrm{C}$. Germination was assessed daily to calculate the total percentage of germination as well as the Germination Velocity Index (GVI). To study the influence of seeding depth on plant emergence, 25 seeds were seeded at $0,20,40$, and $80 \mathrm{~mm}$ in pots with sieved soil. The experiment was arranged in a randomized block design with four replications. Seedling emergence was monitored daily until the $15^{\text {th }}$ day after seeding. After that period, the total percentage of emergence was calculated for each experimental unit, as well as the Emergence Velocity Index (EVI). Formation of normal seedlings and the Germination Velocity Index were different among temperatures and higher germination percentages were observed between $20.3{ }^{\circ} \mathrm{C}$ and $37.5{ }^{\circ} \mathrm{C}$. Tecoma stans seedlings did not germinate when planted at 40 and $80 \mathrm{~mm}$ depth. However, the seedlings placed on the soil surface had an emergence percentage of 72 . At $20 \mathrm{~mm}$ depth, the emergence rate was $31 \%$.
\end{abstract}

Keywords: temperature, light, photoperiod, photoblastism.

RESUMO-Objetivou-se com este trabalho avaliar o efeito da temperatura e luminosidade na germinação, bem como o efeito da profundidade de semeadura na emergência do amarelinho. Nos estudos de influência da temperatura na germinação foram avaliados nove intervalos de temperatura entre $15^{\circ} \mathrm{C}$ e $40^{\circ} \mathrm{C}$. Foi utilizado o delineamento inteiramente casualizado, com cinco repetições e 20 sementes por repetição. A influência da luminosidade foi avaliada com os tratamentos: fotoperiodo com alternância de temperatura, fotoperiodo com temperatura constante, escuro com alternância de temperatura e escuro com temperatura constante. Em ambos os estudos foram calculados a porcentagem e o indice de velocidade de germinação (GSI). A influência da profundidade de semeadura foi avaliada depositando-se 25 sementes a O, 20, 40 e $80 \mathrm{~mm}$ de profundidade, em vasos contendo solo peneirado. $O$ delineamento experimental foi o de blocos ao acaso com quatro repetições. Foram calculados a porcentagem e o indice de velocidade de emergência (ESI). Os intervalos de temperatura testados não influenciaram a protrusão da raiz primária, e a faixa de temperatura ótima para formação de plântulas está entre $26,4{ }^{\circ} \mathrm{C}$ e $37,5^{\circ} \mathrm{C}$. As sementes são fotoblásticas neutras, e a alternância de temperatura não favorece a germinação da espécie. Plântulas de amarelinho não emergiram quando

Recebido para publicação em 15.8.2013 e aprovado em 30.12.2013.

2 Universidade de São Paulo, Piracicaba-SP, Brasil, <fabriciareis@usp.br>; ${ }^{3}$ Universidad de Cuenca, Secretaría de Educación Superior, Ciencia, Tecnología e Innovación, Ecuador; ${ }^{4}$ Proccop, Technical Assistant of Dupont Brasil S/A.

Planta Daninha, Viçosa-MG, v. 32, n. 2, p. 283-290, 2014 
as sementes foram depositadas nas profundidades de 40 e $80 \mathrm{~mm}$, ao passo que sementes posicionadas na superficie do solo apresentaram porcentagem de emergência de 72\%; na profundidade de $20 \mathrm{~mm}$ a emergência foi de 31\%.

Palavras-chave: temperatura, luz, fotoperíodo, fotoblastismo.

\section{INTRODUCTION}

Basic studies on weed biology are scarce particularly on those that infest areas of cultivated pastures. Understanding the behavior of the germination of weed species linking it to environmental factors plays an important role in interpreting the ecological behavior of the species in the field and enables the development of strategies to reduce the potential of the seed bank and thus the decrease in supplying new individuals of undesirable plants (Souza Filho, 1998).

The depth of the soil in which a plant is able to germinate and produce a seedling varies among species and presents ecological and agronomic importance. Greater seedling emergence of coatbuttons when the seeds were deposited on the surface and were partially buried was observed; when deposited at depths greater than $1 \mathrm{~cm}$, there was a reduction in emergence (Guimarães et al, 2002.). Labonia et al. (2009) observed greater emergence of five species of the family Convolvulaceae (morning glory) when seeds were deposited on the soil surface.

Many weed species germinate only when arranged in small soil depths because these seeds, in most cases, require incident light to start the germination process, being called positive photoblastic. According to Benvenuti (1995), as soil depth increases, the light is strongly attenuated; typically seeds of these species when deposited at greater depths are unable to emerge. The temperature also varies with the depth of the soil; in the vicinity of the surface it is very similar and was significantly attenuated after only $5 \mathrm{~cm}$ depth (Gasparim, 2005).

The germinated seed can be considered in two ways. From the viewpoint of plant physiology, the radicle protrusion indicates the end of germination and the subsequent development is considered post-germination.
However, the concept of germination in seed technology involves the development of embryonic structures and the formation of a seedling in which all its contributing parts are evident (Brasil, 1992; Marcos Filho, 2005).

In connection with the germination of weed species described in literature, there are works that use both the primary root protrusion (Carvalho \& Christoffoleti, 2007; Socolowski et al., 2008) and the formation of normal seedlings (Wang et al. 2009). Thus, there is no consensus about the best criterion to be adopted and the results are comparable.

The Tecoma stans species, popularly known as trumpet flower, was introduced in Brazil as ornamental and became later an important weed in cultivated pastures and abandoned areas in the country (Lorenzi, 2008). This species produces lots of seeds with membranous wing (Renó et al., 2007), which are easily spread by wind. This plant also spreads vegetatively, by pieces of stem and root.

Aiming to understand the distribution and establishment of the species and provide information for integrated management programs, the effects of temperature and light on germination and the effects of sowing depth on trumpet flower seedling emergence were evaluated.

\section{MATERIAL AND METHODS}

The research was conducted between the months of November 2011 and August 2012. The seeds were collected in August 2011 in a natural infestation area in cultivated pastures of Escola Superior de Agricultura "Luiz de Queiroz"- USP, Piracicaba, São Paulo. The seeds were previously subjected to germination tests in order to verify the feasibility. All seeds were stored in a kraft paper bag, in a dry chamber at $20^{\circ} \mathrm{C}$ and $50 \% \mathrm{RH}$. The studies that evaluated the temperature and light were 
performed at the Laboratory of Seed Analysis of Escola Superior de Agricultura "Luiz de Queiroz"- USP, Piracicaba, São Paulo.

\section{Temperature}

To determine the effect of temperature, 20 seeds were distributed on three sheets of blotting paper on a Petri dish (diameter $8 \mathrm{~cm}$ ); the amount of water applied corresponded to 2.3 times the weight of the paper. The Petri dishes were incubated at temperatures ranging from $15^{\circ} \mathrm{C}$ to $40{ }^{\circ} \mathrm{C}\left(15.1\right.$ at $17^{\circ} \mathrm{C}$; 17.5 at $19.6^{\circ} \mathrm{C}, 20.3$ at $22.2^{\circ} \mathrm{C}, 23.6$ at $25.6{ }^{\circ} \mathrm{C}, 26.4$ at $28.5^{\circ} \mathrm{C} ; 28.8$ at $30.9{ }^{\circ} \mathrm{C}, 31.7$ at $33.9{ }^{\circ} \mathrm{C}, 34.5$ at $37.5{ }^{\circ} \mathrm{C}, 37.9$ to $40.9{ }^{\circ} \mathrm{C}$ ) in thermogradient table (Van den Berg brand, model 890) under a photoperiod of eight hours. A completely randomized design with five replications was used, and the experiment was repeated twice.

\section{Light and alternating temperature}

To evaluate the effect of light, 25 seeds were placed in transparent plastic boxes $(0.11 \times 0.11 \times 0.03 \mathrm{~m})$, with two sheets of blotting paper $(0.105 \times 0.105 \mathrm{~m})$ moistened with amount of water equivalent to 2.5 times the weight of the paper. The following treatments were evaluated: photoperiod of eight hours a day and alternating temperature $\left(8 \mathrm{~h} / 30^{\circ} \mathrm{C}\right.$ and $\left.16 \mathrm{~h} / 20^{\circ} \mathrm{C}\right)$; photoperiod of eight hours a day at a constant temperature $\left(25^{\circ} \mathrm{C}\right)$; continuous darkness and alternating temperature $\left(8 \mathrm{~h} / 30^{\circ} \mathrm{C}\right.$ and $\left.16 \mathrm{~h} / 20^{\circ} \mathrm{C}\right)$; and continuous dark at a constant temperature $\left(25^{\circ} \mathrm{C}\right)$. The experimental design used was completely randomized with eight replications. Evaluation of germination of seeds stored in the dark was taken in a dark room under green light because its wavelength does not stimulate seed germination.

\section{Sowing depth}

The research was conducted in a greenhouse; during its conduction, the average daily temperature was $29^{\circ} \mathrm{C}$, with maximum of $36^{\circ} \mathrm{C}$ and minimum of $19.5^{\circ} \mathrm{C}$.

The experimental units consisted of plastic pots with $190 \mathrm{~mm}$ diameter, $150 \mathrm{~mm}$ height and capacity for 2.8 liters filled with soil (Eutroferric Red Nitosol) of clayey texture (34\% sand, $13 \%$ silt and $53 \%$ clay). The bottom of the vessel was sealed with filter paper, and soil moisture was monitored gravimetrically, so as to keep a level close to $80 \%$ of the field capacity. Sowing was done by depositing 25 seeds per pot at depths of $0,20,40$ and $80 \mathrm{~mm}$, and covering them with soil to a predefined height. The experimental design used was randomized blocks with four replications.

\section{Forms of evaluation and statistical analysis}

Evaluations of the effect of light and temperature on germination were performed daily according to primary root protrusion and the production of normal seedlings. The primary root protrusion was considered when it had $2 \mathrm{~mm}$ or more in length (Carvalho \& Christoffoleti, 2007). As a normal seedling, were considered those that had the essential structures of the embryo developed (Brasil, 1992).

Evaluations of the effect of sowing depth were performed within 15 days after the experiment was established, and the seedling was considered emerged after the expansion of the cotyledons. With the data, we calculated the germination or emergence speed index (GSI/ESI) and percentage, according to Maguire (1962).

The evaluation of the effect of temperature was performed twice, and the data were analyzed together. On the GSI and germination percentage (normal seedling formation) data, transformations were employed (Box \& Cox, 1964). These data were also used in the germination percentage (normal seedling formation) and GSI (primary root protrusion), when assessing the effect of light.

The nonparametric test based on orders (Conover, 1981) was used in germination percentage data, considering the primary root protrusion in both tests performed in laboratories. Then, an analysis of variance with application of the $\mathrm{F}$ test was made; if significant, the Tukey test at $5 \%$ probability was performed. Furthermore, analysis of the temperature ranges was conducted with the 
use of regression equations. For this, quadratic polynomial equations were fitted to the average temperature intervals of data (Brancalion et al., 2008; Wang et al., 2009.).

\section{RESULTS AND DISCUSSION}

\section{Temperature}

The temperatures did not influence the germination percentage when evaluating primary root protrusion $(\mathrm{p}>0.05$, Table 1$)$. The species Tabebuia rosea, another Bignoniaceae, showed a similar behavior, showing no difference in germination percentages between the temperatures of $15^{\circ} \mathrm{C}$ and $40^{\circ} \mathrm{C}$ (Socolowski \& Takaki, 2007). Socolowski et al. (2008) found no difference in the percentage of germination of trumpet flower seeds between temperatures of $15-40{ }^{\circ} \mathrm{C}$.

The temperatures studied influenced the formation of normal seedlings ( $p<0.05$, Table 1$)$. In the intervals of $15.1-17.0{ }^{\circ} \mathrm{C}$ and 37.9$40.9^{\circ} \mathrm{C}$ the percentages of normal seedling formation decreased, presenting 58 and $75 \%$, respectively (Figure 1). Seeds of Urena lobata, an important weed in pastures, showed similar behavior, where lower percentages of seedlings formed at temperatures of 15 and $40{ }^{\circ} \mathrm{C}$ were observed (Wang et al., 2009).

In cold conditions the metabolic activity is relatively low, which decreases the germination percentage and rate (Okuzanya, 1980). Moreover, high temperatures for long periods may induce protein denaturation. Generally, species with wide distribution feature germination in a wide temperature range (Larcher, 2000).

Unlike the germination percentage, germination speed index (GSI), evaluating the primary root protrusion, were lower as the temperature ranges studied decreased. The same occurred when evaluating the formation of normal seedlings (Figure 1). Socolowski \& Takaki (2007), in research with seeds of T. rosea, saw no difference between the germination rate means, when measured at temperatures of $20,25,30$ and $40{ }^{\circ} \mathrm{C}$.

According to the normal seedlings and GSI formation percentage results, the optimum temperature for germination of trumpet flower is in the range of $26.4{ }^{\circ} \mathrm{C}$ to $37.5{ }^{\circ} \mathrm{C}$ (Table 1). According to Marcos Filho (2005), the optimum temperature for germination may be that in which occurs the most efficient combination of percentage and speed of germination, that is, the maximum germination in the shortest period of time.

As expected, the rate of primary protrusion was higher than that of normal seedlings production, since the primary root is usually the first portion of the seedling developing from germination. The differences in germination percentage are due to not accounting for abnormal seedlings when evaluating the primary root protrusion, resulting in higher values of germination, compared with the production of normal seedlings. Therefore, the issue of primary roots was less affected by temperature when compared with normal seedling formation. This indicates that the formation of shoots of trumpet flower seedlings is more sensitive to temperature changes than the root system and that there are differences in the temperature requirement for the development of different parts of the seedling.

Table 1 - Germination (G\%) and germination speed index (GSI) of Tecoma stans seed in thermogradient table between the temperatures of 15 and $40{ }^{\circ} \mathrm{C}$, in accordance with the production of normal seedlings (PN) and primary root protrusion (PRP). Piracicaba, SP

\begin{tabular}{|c|c|c|c|c|}
\hline \multirow{2}{*}{$\begin{array}{c}\text { Temperature } \\
\left({ }^{\circ} \mathrm{C}\right)\end{array}$} & \multicolumn{2}{|c|}{ PN } & \multicolumn{2}{c|}{ PRP } \\
\cline { 2 - 5 }$\% \mathrm{G}^{1 /}$ & $\mathrm{IVG}^{2 /}$ & $\% \mathrm{G}^{3 /}$ & $\mathrm{GSI}$ \\
\hline $15.1-17.0$ & $58.5 \mathrm{c}$ & $0.92 \mathrm{e}$ & 86.0 & $2.82 \mathrm{~d}$ \\
\hline $17.5-19.6$ & $84.0 \mathrm{ab}$ & $1.79 \mathrm{~d}$ & 97.0 & $4.62 \mathrm{c}$ \\
\hline $20.3-22.2$ & $93.5 \mathrm{a}$ & $2.74 \mathrm{c}$ & 97.0 & $6.44 \mathrm{~b}$ \\
\hline $23.6-25.6$ & $94.5 \mathrm{a}$ & $3.39 \mathrm{bc}$ & 94.0 & $9.04 \mathrm{a}$ \\
\hline $26.4-28.5$ & $92.0 \mathrm{a}$ & $3.88 \mathrm{ab}$ & 95.0 & $9.51 \mathrm{a}$ \\
\hline $28.8-30.9$ & $94.5 \mathrm{a}$ & $3.94 \mathrm{ab}$ & 97.0 & $9.45 \mathrm{a}$ \\
\hline $31.7-33.9$ & $90.7 \mathrm{a}$ & $4.45 \mathrm{a}$ & 96.0 & $8.74 \mathrm{a}$ \\
\hline $34.5-37.5$ & $92.5 \mathrm{a}$ & $4.43 \mathrm{a}$ & 96.0 & $9.25 \mathrm{a}$ \\
\hline $37.9-40.9$ & $75.0 \mathrm{bc}$ & $2.84 \mathrm{c}$ & 91.0 & $8.66 \mathrm{a}$ \\
\hline $\mathrm{Mean}$ & 86.13 & 3.16 & 94.33 & 7.62 \\
\hline $\mathrm{F}$ & $14.88^{* *}$ & $69.78^{* *}$ & $1.48^{\mathrm{ns}}$ & $148.16^{* *}$ \\
\hline $\mathrm{CV}(\%)$ & 24.58 & 8.43 & 6.93 & 8.31 \\
\hline
\end{tabular}

Means followed by the same letter in the column do not differ by Tukey's test at $5 \%$ probability. ${ }^{1 /}$ Data transformed by $\left(\mathrm{x}^{3}\right) ; \stackrel{2}{2}$ data transformed by (" $\mathrm{x}) ; \stackrel{3}{-}$ analysis of variance based on orders; ** $\mathrm{F}$ value significant at $1 \%$ probability; NS value of F not significant at $5 \%$ probability. 

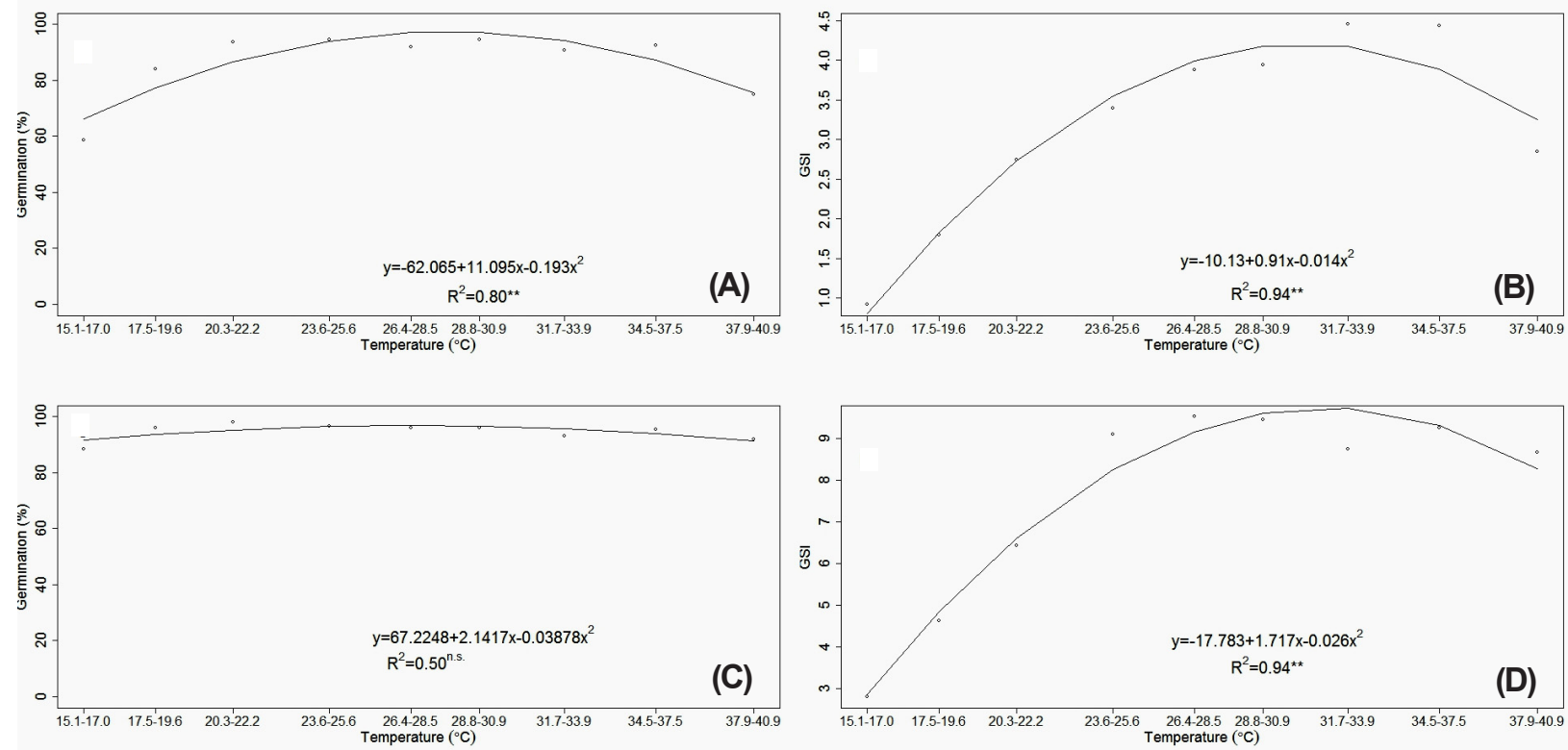

(A) percentage of germination - PN; (B) germination speed index - PN; (C) percentage of germination - PRP; (D) germination speed index - PRP. **value of $\mathrm{F}$ significant at $1 \%$ probability; NS value of $\mathrm{F}$ not significant at $5 \%$ probability; Piracicaba, São Paulo.

Figure 1 - Germination (G\%) and germination speed index (GSI) of Tecoma stans seed in thermogradient table between the temperatures of 15 and $40{ }^{\circ} \mathrm{C}$, in accordance with the production of normal seedlings (PN) and primary root protrusion (PRP).

The adjusted regressions showed highly significant $\mathrm{R}^{2}$, as well as the equation coefficients, for the of normal seedlings germination percentage and the normal seedling germination speed index and primary root protrusion (Figure 1). In the case of regression adjusted for the percentage of germination of the primary root protrusion, the $\mathrm{R}^{2}$ was low (0.5) and not significant (Figure 1). In this particular case, other equations were tested, but all had the same behavior.

\section{Light and alternating temperature}

Although trumpet flower infest areas where shading usually does not occur, such as pastures and abandoned areas, no influence of light was observed to initiate germination, primary root protrusion occurring in the presence and absence of light, which characterizes these seeds as neutral photoblastic. Socolowski et al. (2008) also observed the primary root protrusion of trumpet flower seeds in the presence and absence of light.

Although the trumpet flower seeds germinate in the dark (primary root protrusion), the percentage of normal seedlings of tests conducted in the dark was lower than that of tests driven with light (Table 2). These results indicate that the absence of light may impair the formation of seedlings of this species. Steinbauer \& Grigsby (1957) claim that although most seeds

Table 2 - Germination (G\%) and germination speed index (GSI) of Tecoma stans seeds maintained in the presence and absence of light and temperature being constant $\left(25^{\circ} \mathrm{C}\right)$ and alternating day/night $\left(20-30^{\circ} \mathrm{C}\right)$, according to the production of normal seedlings $(\mathrm{PN})$ and primary root protrusion (PRP). Piracicaba, São Paulo

\begin{tabular}{|c|c|c|c|c|}
\hline \multirow{2}{*}{$\begin{array}{c}\text { Light and } \\
\text { temperature regime }\end{array}$} & \multicolumn{2}{|c|}{$\overline{P N}$} & \multicolumn{2}{|c|}{ PRP } \\
\hline & $\mathrm{G}^{1} \%$ & GSI & $\mathrm{G} \% \%^{-2 /}$ & $\mathrm{IVG}^{\mathrm{l} /}$ \\
\hline Photop. $/ 25^{\circ} \mathrm{C}$ & $93.50 \mathrm{a}$ & $3.56 \mathrm{a}$ & 95.00 & 11.73 \\
\hline Photop. $/ 20-30{ }^{\circ} \mathrm{C}$ & $89.00 \mathrm{a}$ & $2.88 \mathrm{~b}$ & 95.50 & 11.50 \\
\hline Dark $/ 25^{\circ} \mathrm{C}$ & $36.50 \mathrm{~b}$ & $0.93 \mathrm{c}$ & 93.00 & 11.37 \\
\hline Dark $/ 20-30^{\circ} \mathrm{C}$ & $31.50 \mathrm{~b}$ & $0.63 \mathrm{c}$ & 96.50 & 11.25 \\
\hline Mean & 62.63 & 1.99 & 95.00 & 11.47 \\
\hline $\mathrm{F}$ & $330.91^{* *}$ & $175.24 * *$ & $0.87^{\text {ns }}$ & $0.62^{\text {ns }}$ \\
\hline $\mathrm{CV} \%$ & 14.58 & 15.39 & 4.69 & 12.96 \\
\hline
\end{tabular}

Means followed by the same letter in the column do not differ by Tukey's test at $5 \%$ probability. ${ }^{\prime}$ Data transformed by $\left(\mathrm{x}^{2}\right) ; \underline{2}$ analysis of variance based on orders; ** F value significant at $1 \%$ probability; ${ }^{\text {ns }}$ value of $\mathrm{F}$ not significant at $5 \%$ probability. 
germinate both in light and in the dark, some will germinate less or not completely under totally dark conditions.

In the treatments conducted in the dark, some seeds that germinated in the dark originated seedlings whose cotyledons remained within the integument and had stunted hypocotyl. According to Brasil (1992), in order for a seedling to be classified as normal, $50 \%$ or more of the cotyledon must be intact, with no evidence of damage or deterioration of the shoot apex; therefore, seedlings where cotyledons remained within the integument were not counted.

Brancalion et al. (2008) obtained similar results, for although seeds of Heliocarpus popayanensis emit primary root in the absence of light, the percentage of normal seedlings was lower in tests conducted in the dark, when compared with those conducted with light. Wang et al. (2009) found no difference in seedling rate of $U$. lobata when seeds were germinated in light and dark.

Socolowski et al. (2008) observed a higher percentage of trumpet flower seedling emergence in a sunny environment compared to a shady the environment; in addition, it was observed that, in a shade environment, only $1.5 \%$ of the plants had survived 30 days after sowing, the whereas, in full sun, $96.5 \%$ of the seedlings survived, confirming the invasive nature of this species.

Regarding the germination speed index, there was no difference between treatments when primary root protrusion was evaluated. When considering normal seedling, the highest germination speed was observed in the treatment with constant temperature and photoperiod (Table 2).

Alternating temperature did not favor germination (PRP) and trumpet flower normal seedling. It can be observed (Table 2) that there was no difference in the percentage of normal seedlings between treatments conducted in light and dark. Carvalho \& Christoffoleti (2007) observed that the condition of alternating temperature improved the germination of the Amaranthus species. Mondo et al. (2010) also observed more favorable results for percentage and speed of germination under alternating temperature seed Digitaria bicornis.

\section{Sowing depth}

Highest percentage and highest speed of emergence were observed when seeds were deposited on the soil surface (Table 3). No emergence was observed when seeds were deposited at 40 and $80 \mathrm{~mm}$ of soil depth. Wang et al. (2009) found a higher percentage of emergence when seeds of $U$. lobata were deposited on the surface, while the rate of seedling emergence reduced $10 \%$ per $\mathrm{cm}$ deep in the soil.

In deeper layers of the soil, light and seed size are usually limiting factors to emergence (Wang et al., 2009). In fact, the results presented (Table 2) show that trumpet flower is able to germinate in the dark; so the seeds of the species deposited at depths greater than $2 \mathrm{~cm}$ probably germinated, but the length of hypocotyl was not sufficient for seedlings to reach the soil surface. The lack of adequate energy reserves of the seed or its small size has been suggested in other studies as a possible cause of the failure on the seedling emergence in large planting depths (DiasFilho, 1998).

Souza Filho et al. (1998) observed that the species Cassia tora emerged at $8 \mathrm{~cm}$, while $U$. lobata did not. These authors attributed this behavior to the smaller size of the seed of U. lobata. In contrast, Toledo et al. (1993)

Table 2 - Germination (G\%) and germination speed index (GSI) of Tecoma stans seeds maintained in the presence and absence of light and temperature being constant $\left(25^{\circ} \mathrm{C}\right)$ and alternating day/night $\left(20-30^{\circ} \mathrm{C}\right)$, according to the production of normal seedlings (PN) and primary root protrusion (PRP). Piracicaba, São Paulo

\begin{tabular}{|c|c|c|}
\hline Depth $(\mathrm{mm})$ & $\% \mathrm{E}$ & ESI \\
\hline 0 & $72 \mathrm{a}$ & $2.53 \mathrm{a}$ \\
\hline 20 & $31 \mathrm{~b}$ & $0.81 \mathrm{~b}$ \\
\hline $40^{1 /}$ & 0 & 0 \\
\hline $80^{1 /}$ & 0 & 0 \\
\hline Mean & 51.5 & 1.67 \\
\hline F & $47.13^{* *}$ & $875.83^{* *}$ \\
\hline CV \% & 16 & 4.92 \\
\hline
\end{tabular}

Means followed by the same letter in the column do not differ by Tukey's test at $5 \%$ probability. ${ }^{1 /}$ Data transformed by $\left(\mathrm{x}^{2}\right) ; \stackrel{2}{2}$ analysis of variance based on orders; ${ }^{*} \mathrm{~F}$ value significant at $1 \%$ probability; ${ }^{n s}$ value of $\mathrm{F}$ not significant at $5 \%$ probability. 
observed that seedling emergence of Xanthium strumarium occurred almost continuously up to 8 inches deep. However, the emergence of seedlings when seeds were in depth of over $8 \mathrm{~cm}$ was significantly lower. Oxygen concentration decreased with sowing depth (Benvenuti et al., 2001). According to Marcos Filho (2005), low concentrations of oxygen in these conditions can paralyze the germination of many seeds, which may also explain the lack of germination of the species at greater depths.

Trumpet flower seeds can germinate in different light conditions and in a wide range of temperature, with the formation of normal seedlings above $50 \%$ even at temperatures below $20{ }^{\circ} \mathrm{C}$ and above $37^{\circ} \mathrm{C}$. However, sowing depth is a limiting factor for the emergence, so the inversion of soil with cultivation could be a way to control the species. However, this type of operation is not feasible or frequently performed in pastures, which explains the ability of the species to germinate and establish in them.

\section{ACKNOWLEDGMENTS}

To Agronomist Engineer M.Sc. Helena Maria Carmignani Pescarin Chamma, for her cooperation in conducting the tests, and to $\mathrm{CNPq}$ for the grant of a master's scholarship to the first author (Fabricia Cristina dos Reis).

\section{LITERATURE CITED}

BENVENUTI, S. Soil penetrantion and dormancy of Jimsonweed (Datura stramonium) Seeds. Weed Sci., v. 43, n. 3, p. 389-393, 1995.

BENVENUTI, S.; MACCHIA, M.; MIELE, S. Quantitative analysis of emergence of seedlings from buried weed seeds with increasing soil depth. Weed Sci., v. 49, n. 4, p. 528-535, 2001.

BOX, G. E. P.; COX, D. R. An analysis of transformations. J. Royal Stat. Soc., v. 16, n. 2, p. 211-252, 1964.

BRANCALION, P. H. S. et al. Efeito da luz e de diferentes temperaturas na germinação de sementes de Heliocarpus popayanensis L. R. Árvore, v. 32, n. 2, p. 225-232, 2008.

BRASIL. Ministério da Agricultura e Reforma Agrária. Regras para análise de sementes. Brasília: SNDA/DNDV/ CLAV, 1992. 365 p.
CARVALHO, S. J. P.; CHRISTOFFOLETI, P. J. Influência da luz e da temperatura na germinação de cinco espécies de plantas daninhas do gênero Amaranthus. Bragantia, v. 66, n. 4, p. 527-533, 2007.

CONOVER, W. J.; IMAN, R. L. Rank transformations as a bridge between parametric and nonparametric statistics. Am. Stat., v. 35, n. 3, p. 125-133, 1981.

DIAS-FILHO, M. B. Alguns aspectos da ecologia de sementes de duas espécies de plantas invasoras da Amazônia Brasileira: implicações para o recrutamento de plântulas em áreas manejadas. In: GASCON, C.; MOUTINHO, P. (Ed.). Floresta amazônica: dinâmica, regeneração e manejo. Manaus: INPA, 1998. p. 233-248.

GASPARIM, E. et al. Temperatura no perfil do solo utilizando densidades de cobertura e solo nu. Acta Sci. Agron., v. 27, n. 1, p. 107-115, 2005.

GUIMARAES, S. C.; SOUZA, I. F.; PINHO, E. V. R. V. Emergência de Tridax procumbens em função de profundidade de semeadura, do conteúdo de argila no substrato e da incidência de luz na semente. Planta Daninha, v. 20, n. 3, p. 413-419, 2002

LABONIA, V. D. S. et al. Emergência de plantas da família Convolvulaceae influenciada pela profundidade da semente no solo e cobertura com palha de cana-de-açúcar.

Planta Daninha, v. 27, p. 921-929, 2009. (Número Especial)

LARCHER, L. Ecofisiologia vegetal. São Carlos: RiMa, 2000. 531 p.

LORENZI, H. Plantas daninhas do Brasil: terrestres, aquáticas, parasitas e tóxicas. 4.ed. Nova Odessa: Instituto Plantarum, 2008. 640 p.

MAGUIRE, J. D. Speed of germination-aid in selection and evaluation for seedling emergence and vigor. Crop Sci., v. 2, n. 1, p. 176-177, 1962.

MARCOS FILHO, J. Fisiologia de sementes de plantas cultivadas. Piracicaba: FEALQ, 2005. 495 p.

MONDO, V. H. V. et al. Efeitos da luz e temperatura na germinação de sementes de quatro espécies de plantas daninhas do gênero Digitaria. R. Bras. Sementes, v. 32, n. 1, p. 131-137, 2010.

OKUZANYA, O. T. Germination and growth of Celosia cristata L., under light and temperature regimes. Am. J. Bot., v. 67, n. 6 , p. $854-858,1980$.

RENÓ, L. R.; MOSCHETA, I. S.; BRACCINI, A. L. Morfoanatomia do fruto e semente de amarelinho (Tecoma stans (L.) Kunth - Bignoniaceae). R. Bras. Sementes, v. 29, n. 3, p. 18-30, 2007. 
SOCOLOWSKI, F.; TAKAKI, M. Germinação de sementes e emergência de plântulas de Tabebuia rosea (Bertoloni) A.P. de Candolle (Bignoniaceae), uma espécie exótica com potencial invasor. R. Árvore, v. 31, n. 2, p. 229-238, 2007.

SOCOLOWSKI, F.; VIEIRA, D. C. M.; TAKAKI, M. Interaction of temperature and light on seed germination in Tecoma stans L. Juss. ex Kunth (Bignoniaceae). Braz. Arch. Biol. Technol., v. 51, n. 4, p. 723-730, 2008.

SOUZA FILHO, A. P. S. et al. Efeitos de diferentes substratos e da profundidade de semeadura na germinação de sementes de mata-pasto e malva. Planta Daninha, v. 16, n. 1, p. 67-74, 1998.
STEINBAUER, G. P.; GRIGSBY, B. Interaction of temperature, light, and moistening agent in the germination of weed seeds. Weeds, v. 5, n. 3, p. 175-182, 1957.

TOLEDO, R. E. B.; KUVA, M. A.; ALVES, P. L. C. A. fatores que afetam a germinação e a emergência de Xanthium strumarium 1.: dormência, qualidade da luz e profundidade de semeadura. Planta Daninha, v. 11, n. 1/2, p. 15-20, 1993.

WANG, J. et al. Factors affecting seed germination of Cadillo (Urena lobata). Weed Sci., v. 57, n. 1, p. 31-35, 2009. 